\title{
Long-Term Leaf Production Response to Elevated Atmospheric Carbon Dioxide and Tropospheric Ozone
}

\author{
Alan F. Talhelm, ${ }^{1 *}$ Kurt S. Pregitzer, ${ }^{1}$ and Christian P. Giardina ${ }^{2}$ \\ ${ }^{1}$ College of Natural Resources, University of Idaho, Moscow, Idaho 83844, USA; ${ }^{2}$ USDA Forest Service, Pacific Southwest Research \\ Station, Institute of Pacific Islands Forestry, Hilo, Hawaii 96720, USA
}

\begin{abstract}
Elevated concentrations of atmospheric $\mathrm{CO}_{2}$ and tropospheric $\mathrm{O}_{3}$ will profoundly influence future forest productivity, but our understanding of these influences over the long-term is poor. Leaves are key indicators of productivity and we measured the mass, area, and nitrogen concentration of leaves collected in litter traps from 2002 to 2008 in three young northern temperate forest communities exposed to elevated $\mathrm{CO}_{2}$ and/or elevated $\mathrm{O}_{3}$ since 1998. On average, the overall effect of elevated $\mathrm{CO}_{2}$ $\left(+\mathrm{CO}_{2}\right.$ and $+\mathrm{CO}_{2}+\mathrm{O}_{3}$ versus ambient and $\left.+\mathrm{O}_{3}\right)$ was to increase leaf mass by $36 \%$ whereas the overall effect of elevated $\mathrm{O}_{3}$ was to decrease leaf mass by $13 \%$, with similar effects on stand leaf area. However, there were important $\mathrm{CO}_{2} \times \mathrm{O}_{3} \times$ year interactions wherein some treatment effects on leaf mass changed dramatically relative to ambient from 2002 to 2008. For example, stimulation by the $+\mathrm{CO}_{2}$ treatment decreased (from +52 to $+25 \%$ ),
\end{abstract}

whereas the deleterious effects of the $+\mathrm{O}_{3}$ treatment increased (from -5 to $-18 \%$ ). In comparison, leaf mass in the $+\mathrm{CO}_{2}+\mathrm{O}_{3}$ treatment was similar to ambient throughout the study. Forest composition influenced these responses: effects of the $+\mathrm{O}_{3}$ treatment on community-level leaf mass ranged from +2 to $-19 \%$. These findings are evidence that community composition, stand development processes, $\mathrm{CO}_{2}$, and $\mathrm{O}_{3}$ strongly interact. Changes in leaf nitrogen concentration were inconsistent, but leaf nitrogen mass $\left(\mathrm{g} \mathrm{m}^{-2}\right)$ was increased by elevated $\mathrm{CO}_{2}(+30 \%)$ and reduced by elevated $\mathrm{O}_{3}(-16 \%)$, consistent with observations that nitrogen cycling is accelerated by elevated $\mathrm{CO}_{2}$ but retarded by elevated $\mathrm{O}_{3}$.

Key words: carbon dioxide; leaf area; long-term; nitrogen cycling; northern temperate forests; ozone; stand age; species dominance.
Received 13 June 2011; accepted 19 September 2011

Electronic supplementary material: The online version of this article (doi:10.1007/s10021-011-9493-z) contains supplementary material, which is available to authorized users.

Author Contributions: AFT analyzed the data and wrote the paper with KSP and CPG. KSP and CPG conceived the research and managed its completion.

*Corresponding author; e-mail: atalhelm@uidaho.edu

\section{INTRODUCTION}

Industrialization has significantly increased the concentrations of atmospheric carbon dioxide $\left(\mathrm{CO}_{2}\right)$ and tropospheric ozone $\left(\mathrm{O}_{3}\right)$, with greater increases predicted over the next century (Dentener and others 2006; IPCC 2007). Both changes have strong ecological impacts: $\mathrm{CO}_{2}$ typically stimulates plant productivity (Ainsworth and Long 2005), whereas $\mathrm{O}_{3}$ is phyto-toxic to a range of plant 
species (Chappelka and Samuelson 1998; Wittig and others 2009). However, despite the large role forest ecosystems play in the global carbon (C) cycle, there is still considerable uncertainly in how changes in atmospheric composition will affect the magnitude and even the direction of forest C storage (Nabuurs and others 2007). This uncertainty hinders efforts to model regional- to global-scale impacts and develop confidence in forest-based C mitigation programs (Nabuurs and others 2007), but relatively few experiments have examined the long-term response of forest ecosystems to elevated $\mathrm{CO}_{2}$ and/or $\mathrm{O}_{3}$.

Several of the experiments which have examined the long-term forest response to elevated $\mathrm{CO}_{2}$ have used the free-air $\mathrm{CO}_{2}$ enrichment (FACE) technology that minimizes changes to other environmental factors, while allowing for in situ exposure of large trees to increased concentrations of trace gases (Hendrey and others 1999). Results from these forest FACE experiments have emphasized the importance of leaf properties, including physiology, chemistry, and mass, in determining the response of forests to elevated $\mathrm{CO}_{2}$ (McCarthy and others 2006; Finzi and others 2007). These leaf properties are directly affected by elevated $\mathrm{CO}_{2}$, but are also affected by factors such as nitrogen $(\mathrm{N})$ availability (McCarthy and others 2006) and species identity (Cotrufo and others 2005), which express important interactions with elevated $\mathrm{CO}_{2}$. Although at least some of these factors are important determinants of the forest response to elevated $\mathrm{O}_{3}$ (Chappelka and Samuelson 1998), the number of experiments that have exposed forest systems to both elevated $\mathrm{O}_{3}$ and elevated $\mathrm{CO}_{2}$ is too few to draw similar conclusions (Wittig and others 2009).

Although there is considerable evidence demonstrating that $\mathrm{CO}_{2}$ and $\mathrm{O}_{3}$ influence the physiology, productivity, and composition of forests, it is less clear how these influences change as stands develop (Körner 2006). Resource (light, water, N) availability typically decreases as stands develop (Ryan and others 1997), and although this shift has the potential to substantially change how forests respond to $\mathrm{CO}_{2}$ and $\mathrm{O}_{3}$, the interaction between stand development and these trace gases has not often been examined. For example, although some research indicates that forests can sustain increased productivity under elevated $\mathrm{CO}_{2}$ by enhancing $\mathrm{N}$ uptake (Finzi and others 2007), few studies have followed forests through important stand development phases (for example, establishment, canopy closure, age-related declines in stand productivity) to examine whether the early stimulation of plant productivity by elevated $\mathrm{CO}_{2}$ persists as stands mature after reaching maximum productivity (Körner 2006).

To date, the Rhinelander FACE experiment is the only long-term forest experiment examining both the independent and interactive effects of $\mathrm{CO}_{2}$ and $\mathrm{O}_{3}$ and the only forest FACE experiment designed to examine how competitive interactions among species and genotypes will modify ecosystem responses to these trace gases. In addition, the development of these stands from densely planted seedlings over the 11-year duration of the experiment provides the opportunity for unique insights into how the response of forests to $\mathrm{CO}_{2}$ and $\mathrm{O}_{3}$ changes during stand development.

Previous studies at Rhinelander FACE have shown that leaf litter mass and leaf litter $\mathrm{N}$ mass increased under elevated $\mathrm{CO}_{2}$ and decreased under elevated $\mathrm{O}_{3}$ (Liu and others 2007), whereas green leaf $\mathrm{N}$ concentrations were unaffected by the treatments (Zak and others 2007). However, these and other previous studies have been limited to short-term observations or to a subset of the species and communities included in the experiment. These are critical limitations given that leaf litter production is a strong predictor of ecosystem productivity (King and others 2005; Litton and others 2007) and a sensitive assay of ecosystem response to changes in atmospheric chemistry (Liu and others 2007). Therefore, the goal of this study was to use the annual leaf litterfall data from Rhinelander FACE to assess the response of both individual species (aspen, maple, and birch) and communities (aspen-only, aspen-maple, aspenbirch) to elevated $\mathrm{O}_{3}$ and/or $\mathrm{CO}_{2}$ and to identify how the relative influences of $\mathrm{O}_{3}$ and $\mathrm{CO}_{2}$ on leaf litter production changed as these stands aged over the 7-year period between 2002 and 2008, after which, the experiment was harvested. To do this, we focused on five variables: leaf litter mass ( $L_{\text {mass }}$, $\left.\mathrm{g} \mathrm{m}^{-2}\right)$, leaf litter area $\left(L_{\text {area }}, \mathrm{m}^{2} \mathrm{~m}^{-2}\right)$, leaf litter $\mathrm{N}$ concentration $\left(N_{\text {conc }}, \mathrm{mg} \mathrm{g}^{-1}\right)$, leaf litter $\mathrm{N}$ mass $\left(N_{\text {mass }}, \mathrm{g} \mathrm{N} \mathrm{m}^{-2}\right)$, and species canopy dominance (as measured by proportion of aspen $L_{\text {mass }}$ in mixed communities, \%). Inter-annual variability in plant production at Rhinelander FACE has previously been described (Kubiske and others 2006), so here we specifically conducted our statistical analyses to test for trends through time.

We had several hypotheses in regards to the response of leaf litter properties to the fumigation treatments. First, we expected that because canopy development was thought to be nearly or fully complete in two of the three communities in 2003 (Norby and others 2005), $L_{\text {mass }}$ and $L_{\text {area }}$ would maintain their responses to the fumigation 
treatments over the 7-year sampling period: a positive factorial elevated $\mathrm{CO}_{2}$ response $(+45 \%$ in $\left.2003 L_{\text {mass }}\right)$, a negative factorial elevated $\mathrm{O}_{3}$ response $(-23 \%)$, and no significant interaction between $\mathrm{CO}_{2}$ and $\mathrm{O}_{3}$ (King and others 2005). However, we did expect that the response to $\mathrm{CO}_{2}$ and $\mathrm{O}_{3}$ would vary by species and communities because previous results had observed these effects for productivity (King and others 2005) and stem growth (Kubiske and others 2007). For instance, in results through 2003 for wood production, the reduction caused by the $+\mathrm{O}_{3}$ treatment relative to ambient varied from $-8.9 \%$ (aspen-maple community) to $-27 \%$ (aspen-only community; King and others 2005). Lastly, we predicted that there would be no significant effect of the fumigation treatments on $N_{\text {conc }}$ but that $N_{\text {mass }}$ would respond proportionately with $L_{\text {mass }}$.

\section{Materials AND Methods}

The FACE experiment in Rhinelander, Wisconsin, USA $\left(45^{\circ} 40.5^{\prime} \mathrm{N}, 89^{\circ} 37.5^{\prime} \mathrm{W}, 490\right.$ m.a.s.l.) consisted of twelve $30-\mathrm{m}$ diameter rings, arranged in three randomized complete blocks (Dickson and others 2000). Treatments included factorial $\mathrm{CO}_{2}$ and $\mathrm{O}_{3}$ fumigations, with both ambient and elevated levels of each trace gas randomly assigned within each block. Fumigation began in 1998 and occurred during the daylight hours of the growing season (bud burst to leaf off). Average annual concentrations during fumigation are approximately $40-55 \mathrm{nl} \mathrm{L}^{-1}$ for elevated $\mathrm{O}_{3}$ (elevated average: $45 \mathrm{nl} \mathrm{l}^{-1}$, ambient average: $36 \mathrm{nl} \mathrm{l}^{-1}$ ) and 515$540 \mu \mathrm{l} \mathrm{l}^{-1}$ for elevated $\mathrm{CO}_{2}$ (elevated average: $531 \mu \mathrm{l}^{-1}$, ambient average: $374 \mu \mathrm{l}^{-1}$ ). Soils at the site are Alfic Haplorthods (Pandus series) with a sandy loam Ap horizon overlaying a sandy clay loam Bt horizon. More detailed descriptions of the experimental design, fumigation technique, and fumigation performance can be found in Dickson and others (2000). Annual data on length of the fumigation season, average $\mathrm{CO}_{2}$ and $\mathrm{O}_{3}$ concentrations, and meteorological variables are provided in Appendix Tables 1 and 2 (Supplementary material).

Small trees $(<25 \mathrm{~cm}$ tall) initiated from potted stock were planted in the rings during July 1997. Half of each ring was planted at $1 \mathrm{~m} \times 1 \mathrm{~m}$ intervals with five different aspen (Populus tremuloides Michx.) genotypes representing a range of responsiveness to elevated $\mathrm{O}_{3}$ or elevated $\mathrm{CO}_{2}$ (Dickson and others 2000). The remaining two quarters of each FACE ring were mixed communities planted with either paper birch (Betula papyrifera Marsh.) or sugar maple (Acer saccharum Marsh.) at equal densities with a single aspen genotype at $1 \mathrm{~m} \times 1 \mathrm{~m}$ spacing.

In 2002 and 2003, four litter traps $\left(0.15 \mathrm{~m}^{2}\right)$ were used to collect leaf litter from the aspen-maple and aspen-birch communities in each ring, with eight litter traps in the aspen-only community of each ring (Liu and others 2007). Starting in 2004, the number of traps in the aspen-only community was increased to twelve and the number of traps in the aspen-birch community was increased to six. Leaf litter was collected bi-weekly during the period of active leaf senescence (late August through early November), and approximately monthly during the rest of the growing season. After collection, the leaf litter samples were sorted by species. A subsample (10-15 leaves) from the litter collected in each community in each ring during September and October was analyzed for leaf area using the LI-3100 Leaf Area Meter (Li-Cor Biosciences, Lincoln, NE, USA). Both the overall sample and the subsample were then oven dried to a constant mass and weighed. Specific leaf area (SLA, $\mathrm{cm}^{2} \mathrm{~g}^{-1}$ ) of the litter was determined for the subsample (data not shown) and then applied to the overall sample to determine $L_{\text {area }}$. Collections outside of September and October not sub-sampled for leaf area analysis ( $\sim 15 \%$ of overall biomass) were assigned SLA values from the nearest sub-sampling date. Leaf area measurements were not made in the aspen-maple community during 2003 and 2004. Because SLA varied dramatically among communities (by $\sim 20 \%$ ) and changed consistently through time $(P<0.01)$ in the other two communities, we felt our best option to supply these missing data was to substitute the average aspenmaple community SLA values in 2002 and 2005 for the $2003 / 2004$ values. Annual $L_{\text {mass }}$ and $L_{\text {area }}\left(\mathrm{m}^{2}\right.$ $\mathrm{m}^{-2}$ ) were the sums of $L_{\text {mass }}$ and $L_{\text {area }}$ collected over the entire growing season.

The samples collected from throughout the growing season were ground and used to create a biomass-weighted composite annual sample for $\mathrm{N}$ analysis using a Costech (Valencia, CA) Elemental Combustion System 4010. Annual leaf $N_{\text {mass }}$ (g N $\mathrm{m}^{-2}$ ) was calculated by multiplying annual $L_{\text {mass }}(\mathrm{g}$ $\left.\mathrm{m}^{-2}\right)$ by the $N_{\text {conc }}\left(\mathrm{mg} \mathrm{g}^{-1}\right)$ of the annual sample. All of the measurements were completed at the species-level within each community. Except in the case of $N_{\text {conc }}$ community-level data in the aspenbirch and aspen-maple communities were simply the sum of the results for the individual species within that community. Community $N_{\text {conc }}$ for the aspen-birch and aspen-maple communities was calculated by dividing the combined $N_{\text {mass }}$ of the 
two species within each community by the combined $L_{\text {mass }}$ of those two species. For the aspenbirch and aspen-maple communities, we calculated the canopy dominance of aspen in terms of its proportion of the total community $L_{\text {mass }}$.

\section{Statistical Analysis}

The statistical model was a randomized complete block with a split-plot design; the analyses were conducted using the SAS statistical package (Version 9.1.3, SAS Institute, Cary, NC). These tests used type III sums of squares within a repeated measures analysis of variance (Proc Mixed) and post-hoc least squared means adjusted for multiple comparisons. Block was considered a random effect (Parsons and others 2008; Riikonen and others 2008). Because we were more interested in trends through time rather than annual variability, we used year as a continuous rather than categorical variable. With year as a continuous variable, significant year effects reflect changes through time (trends) and significant treatment $\times$ year interactions are evidence to reject hypotheses that the rate of change (slope of the trend) was similar among treatments (Littell and others 1996). Starting with the highest-level interaction terms, non-significant $(P \geq 0.1)$ interactions between year and fumigation treatments or community were iteratively removed from the model until the only factors that remained were main effects $\left(\mathrm{CO}_{2}, \mathrm{O}_{3}\right.$, community, year, and interactions between the first three of these) and significant interactions with year (Littell and others 1996). When year or an interaction with year was significant we used the solution option within SAS, which provides estimates of the rate of change through time and uses a t-test to determine whether these rates are significantly different from zero. When significant treatment $\times$ year interactions occurred, we also examined changes in the relative size of the treatment effects (for example, $\left[+\mathrm{CO}_{2}\right.$ /ambient -1$\left.] \times 100\right)$ through time using linear regression (Proc Reg; after Norby and Iversen 2006). We should point out that when using this regression analysis for significant $\mathrm{CO}_{2} \times \mathrm{O}_{3} \times$ year interactions, each of the four fumigation treatments are considered as separate treatments rather than factorial treatments. We conducted the overall analyses using community-level data, but we also conducted separate tests for each community individually and explore these results when there were significant community effects in the overall results. Furthermore, data were analyzed for each community component (species) individually to provide mechanistic detail (community and species results provided in Appendix). Data for the proportional dominance (in terms of percent of community $L_{\text {mass }}$ ) of aspen in the mixed-species communities were arcsine transformed to meet the assumption of normality. We used an alpha equal to 0.05 to determine statistical significance, but we report results where $0.05 \leq P<0.10$ because nearly significant differences in a study with necessarily low replication may have biological significance (for example, Johnson and others 2004; Norby and Iversen 2006). Data reported throughout are means \pm standard error.

\section{Results}

\section{Experiment-Wide}

As main effects, elevated $\mathrm{CO}_{2}$ significantly increased both leaf mass $\left(L_{\text {mass }}\right.$. Figure 1$)$ and leaf

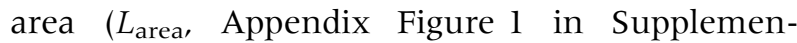
tary material), whereas elevated $\mathrm{O}_{3}$ significantly decreased $L_{\text {mass }}$ and $L_{\text {area }}$ (Figure 1; Appendix Figure 1 and Table 1 in Supplementary material). There was no significant $\mathrm{CO}_{2}$ effect on leaf litter $\mathrm{N}$ concentration $\left(N_{\text {conc }}\right)$, but there was a modest $\mathrm{O}_{3}$ effect (Figure 2; Table 1). However, the effects of $\mathrm{CO}_{2}$ and $\mathrm{O}_{3}$ on leaf litter $\mathrm{N}$ mass $\left(N_{\text {mass, }}\right.$ Figure 3$)$ were similar to those for $L_{\text {mass }}$ (Table 1). Of the measured properties, only $L_{\text {area }}$ exhibited a consistent overall change during the study period $\left(+0.12 \pm 0.03 \mathrm{~m}^{2} \mathrm{~m}^{-2} \mathrm{y}^{-1}, P<0.001\right.$, Appendix Figure 1 in Supplementary material).

In addition to the overall effects of $\mathrm{CO}_{2}$ and $\mathrm{O}_{3}$ on $L_{\text {mass }}, L_{\text {arear }}$ and $N_{\text {mass, }}$ each of these properties had significant $\mathrm{CO}_{2} \times \mathrm{O}_{3} \times$ year, community $\times$ year, and $\mathrm{CO}_{2} \times \mathrm{O}_{3} \times$ community interactions (Table 1). The significant interactions with year denote differences in trends through time. For $L_{\text {mass }} L_{\text {arear }}$ and $N_{\text {mass }}$ the difference between trees in the $+\mathrm{CO}_{2}$ treatment and those in both the ambient and $+\mathrm{CO}_{2}+\mathrm{O}_{3}$ treatments $\left(+\mathrm{CO}_{2} /\right.$ ambient and $+\mathrm{CO}_{2}+\mathrm{O}_{3} /+\mathrm{CO}_{2}$ ) diminished through time $\left(r^{2} \geq 0.578, P \leq 0.048\right.$, Table 2 for $L_{\text {mass; }}$ effect size data not shown for $L_{\text {area }}$ and $\left.N_{\text {mass }}\right)$. In contrast, the difference between trees in the $+\mathrm{O}_{3}$ treatment and those in both the ambient and $+\mathrm{CO}_{2}+\mathrm{O}_{3}$ treatments increased through time $\left(r^{2} \geq 0.481, P \leq 0.084\right)$, except for $+\mathrm{O}_{3}$ /ambient for $N_{\text {mass }}\left(r^{2}=0.425\right.$, $P=0.113)$. However, the main effects of $\mathrm{CO}_{2}$ and $\mathrm{O}_{3}$ did not change significantly through time $(P>0.2$, Table 2$)$. The $\mathrm{CO}_{2} \times \mathrm{O}_{3} \times$ community and community $\times$ year interactions for $L_{\text {mass }}, L_{\text {area }}$ and $N_{\text {mass }}$ are explored below in the sub-sections for each community. There was a modest $\mathrm{CO}_{2} \times$ community $\times$ year interaction for $N_{\text {conc }}$ 

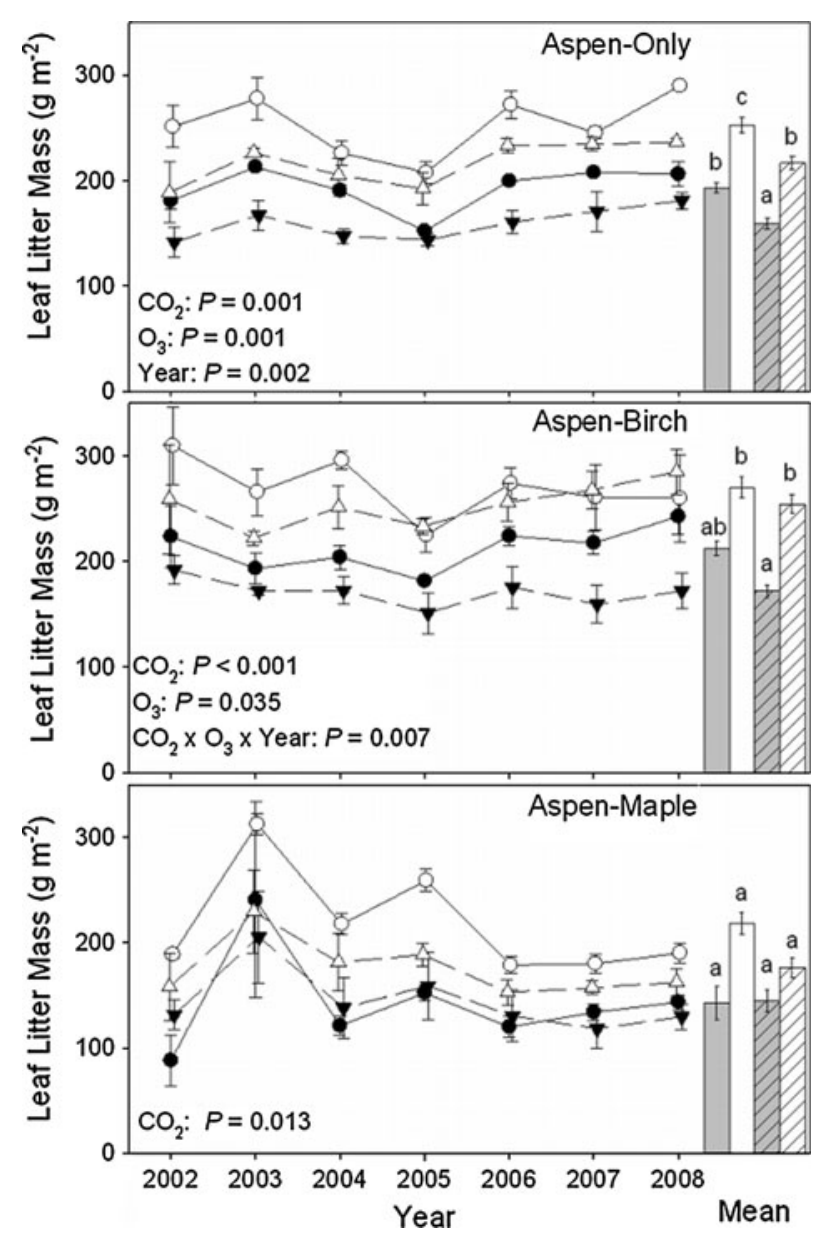

Figure 1. Annual $L_{\text {mass }}\left(\mathrm{g} \mathrm{m}^{-2}\right)$ in the three community types for the ambient (filled circles, filled bar), $+\mathrm{CO}_{2}$ (empty circles, empty bar), $+\mathrm{O}_{3}$ (solid triangles, filled hatched bar), and $+\mathrm{CO}_{2}+\mathrm{O}_{3}$ (empty triangle, empty hatched bar). Bar graphs are means over the entire collection period. Error bars are \pm 1 SE. Reported ANOVA $P$ values are from repeated measures analyses within each community. Overall statistical results are found in Table 1; full statistical results for each community are in Appendix Table 3 (Supplementary material). Letters denote significant differences in pair-wise comparisons $(P<0.05)$ among the treatments within a community.

that resulted from non-significant $\mathrm{CO}_{2}$ effects that increased with time in the aspen-only community but decreased with time in the other two communities (Table 1; Figure 2).

Aspen was a much higher proportion of total community $L_{\text {mass }}$ in the aspen-maple community than in the aspen-birch community $(84.0 \pm 1.4 \%$ vs. $39.6 \pm 1.6 \%$, Figure 4$)$. Trends in the aspen proportion through time varied by community (Table 1), increasing in the aspen-birch community and decreasing in the aspen-maple community $\left(1.3 \pm 0.7 \% \mathrm{y}^{-1}, P=0.061\right.$ vs. $-2.1 \pm 0.7 \% \mathrm{y}^{-1}$, $P=0.003$, Appendix Table 3 in Supplementary

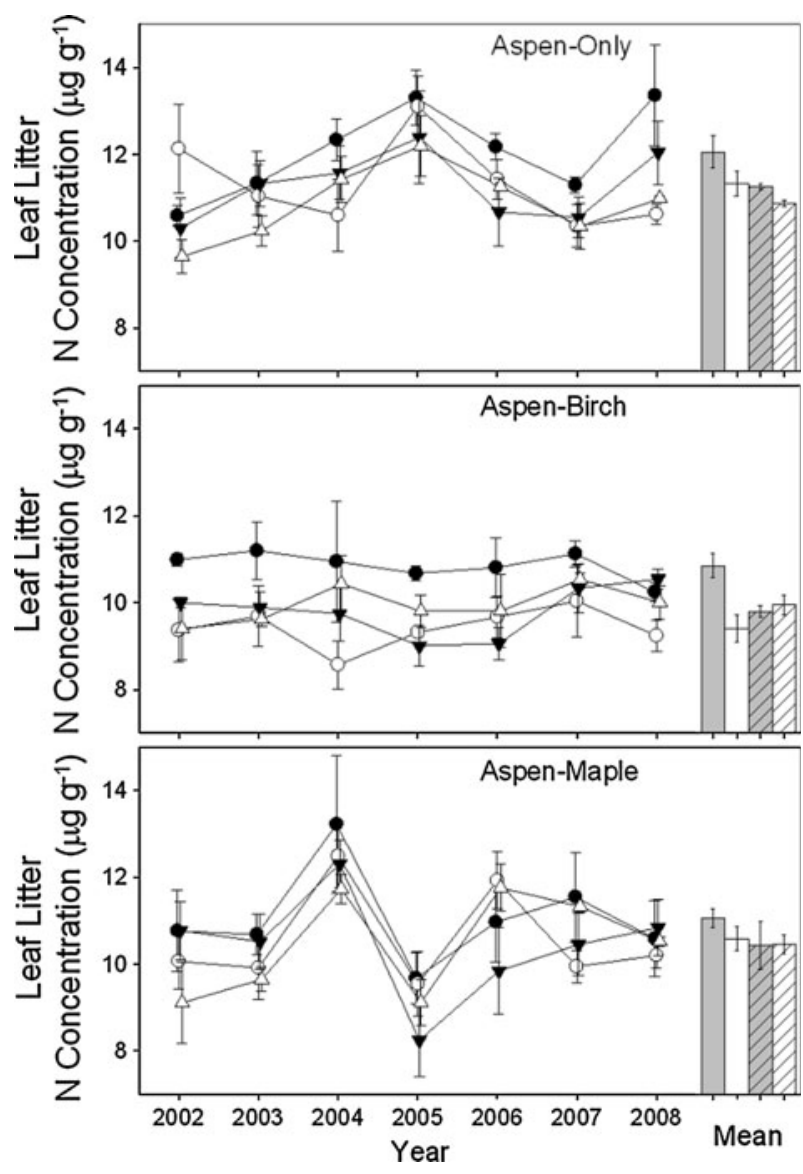

Figure 2. Annual leaf $N_{\text {conc }}\left(\mathrm{mg} \mathrm{g}^{-1}\right)$ in the three community types for each fumigation treatment. Symbols and bars as in Figure 1. Treatment differences within each community were not significant $(P>0.05)$. Overall statistical results are found in Table 1 ; full statistical results for each community are in Appendix Table 3 (Supplementary material).

material). Overall, elevated $\mathrm{CO}_{2}$ increased the proportion of aspen in the mixed-species communities from $57.4 \pm 2.6 \%$ to $66.2 \pm 3.0 \%(P=0.062$, Figure 4). However, pair-wise differences were only significant when comparing the $+\mathrm{CO}_{2}$ treatment with the ambient treatment in the aspen-maple community $\left(P=0.033, \mathrm{CO}_{2} \times \mathrm{O}_{3} \times\right.$ community: $P=0.001)$.

\section{Aspen-Only Community}

In the aspen-only community, there were gradual increases through time in $L_{\text {mass }}, L_{\text {arear }}$ and $N_{\text {mass }}$ (Figure 1; Appendix Table 3 and Figure 1 in Supplementary material). There was no significant increase through time in $N_{\text {mass }}$ in the $+\mathrm{CO}_{2}$ treatment $\left(P=0.846 ; \mathrm{CO}_{2} \times \mathrm{O}_{3} \times\right.$ year: $\left.P=0.081\right)$, but the relative effects of the treatments on $N_{\text {mass }}$ did not change consistently through time $(P>0.13)$. 
Table 1. Experiment-Wide ANOVA $P$ Values

\begin{tabular}{|c|c|c|c|c|c|}
\hline Source & $\begin{array}{l}L_{\text {mass }} \\
\left(\mathrm{g} \mathrm{m}^{-2}\right)\end{array}$ & $\begin{array}{l}L_{\text {area }} \\
\left(\mathrm{m}^{2} \mathrm{~m}^{-2}\right)\end{array}$ & $\begin{array}{l}N_{\text {conc }} \\
\left(\mathrm{mg} \mathrm{g}^{-1}\right)\end{array}$ & $\begin{array}{l}N_{\text {mass }} \\
\left(\mathrm{g} \mathrm{N} \mathrm{m}^{-2}\right)\end{array}$ & $\begin{array}{l}\text { Aspen dominance } \\
\left(\% \text { of } L_{\text {mass }}\right)\end{array}$ \\
\hline $\mathrm{CO}_{2}$ & $<0.001(+36 \%)$ & $0.001(+31 \%)$ & $0.143(-4 \%)$ & $0.003(+30 \%)$ & $0.062(+15 \%)$ \\
\hline $\mathrm{O}_{3}$ & $0.018(-13 \%)$ & $0.004(-18 \%)$ & $0.064(-4 \%)$ & $0.012(-16 \%)$ & $0.375(-6 \%)$ \\
\hline $\mathrm{CO}_{2} \times \mathrm{O}_{3}$ & 0.154 & 0.179 & 0.925 & 0.238 & 0.845 \\
\hline Community (comm.) & 0.001 & 0.046 & 0.002 & 0.106 & $<0.001$ \\
\hline $\mathrm{CO}_{2} \times$ comm & 0.313 & 0.025 & 0.264 & 0.967 & $<0.001$ \\
\hline $\mathrm{O}_{3} \times$ comm. & 0.433 & 0.127 & 0.613 & 0.104 & 0.424 \\
\hline $\mathrm{CO}_{2} \times \mathrm{O}_{3} \times$ comm & 0.011 & 0.005 & 0.186 & 0.001 & $<0.001$ \\
\hline Year & 0.691 & $<\mathbf{0 . 0 0 1}$ & 0.166 & 0.670 & 0.420 \\
\hline $\mathrm{CO}_{2} \times$ year & 0.599 & 0.969 & 0.739 & 0.643 & - \\
\hline $\mathrm{O}_{3} \times$ year & 0.444 & 0.650 & 0.204 & 0.255 & - \\
\hline $\mathrm{CO}_{2} \times \mathrm{O}_{3} \times$ year & 0.028 & 0.017 & 0.103 & 0.005 & - \\
\hline Comm. $\times$ year & 0.001 & 0.012 & 0.803 & 0.002 & 0.001 \\
\hline $\mathrm{CO}_{2} \times$ comm.$\times$ year & - & - & 0.075 & - & - \\
\hline $\mathrm{O}_{3} \times$ comm $\times$ year & - & - & - & - & - \\
\hline $\mathrm{CO}_{2} \times \mathrm{O}_{3} \times$ comm. $\times$ year & - & - & - & - & - \\
\hline
\end{tabular}

$L_{\text {mass }}$ leaf litter mass; $L_{\text {area }}$ leaf litter area; $N_{\text {conc }}$ leaf nitrogen concentration; $N_{\text {mass }}$ leaf $N$ mass. Results from repeated measures analyses. Fumigation main effect sizes in parentheses. Effects with $P<0.05$ are in bold. Non-significant interactions $(P \geq 0.1)$ between year and species or $\mathrm{CO}_{2} / \mathrm{O}_{3}$ removed from the analysis (see "Materials and methods" section) denoted with "-".

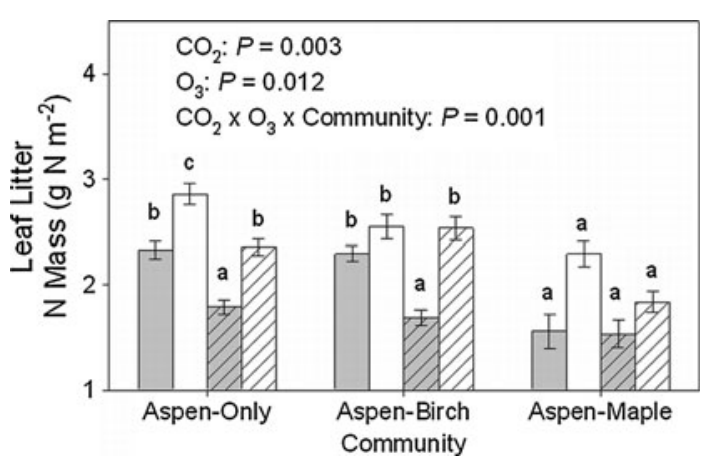

Figure 3. Mean annual leaf $N_{\text {mass }}\left(\mathrm{g} \mathrm{m}^{-2}\right)$ for each treatment in the three forest communities averaged across all years. Bars as in Figure 1. Overall statistical results are from repeated measures ANOVA. Letters denote significant differences in pair-wise comparisons $(P<0.05)$ among the treatments within a community. Overall statistical results are found in Table 1; full statistical results for each community are in Appendix Table 3 (Supplementary material).

Elevated $\mathrm{CO}_{2}$ increased $L_{\text {mass, }} L_{\text {arear }}$ and $N_{\text {mass }}$ $(P \leq 0.001)$, whereas elevated $\mathrm{O}_{3}$ caused these properties to decrease $(P \leq 0.001)$. For $N_{\text {conc }}$, the relative effects of the treatments changed through time $\left(\mathrm{CO}_{2} \times \mathrm{O}_{3} \times\right.$ year: $P=0.051$; Figure 2$)$. Here, the effect of the $+\mathrm{CO}_{2}$ treatment relative to ambient changed from $+15 \%$ in 2002 to $-20 \%$ in 2008 , whereas the effect of the $+\mathrm{O}_{3}$ treatment relative to ambient changed from -3 to $-10 \%$ $\left(r^{2} \geq 0.577, P \leq 0.048\right.$ for both).

\section{Aspen-Birch Community}

For the aspen-birch community, only $L_{\text {area }}$ showed a consistent overall increase with time (Appendix Table 3 and Figure 1 in Supplementary material). $L_{\text {mass }}, L_{\text {arear }}$ and $N_{\text {mass }}$ were all increased by elevated $\mathrm{CO}_{2}$ and decreased by elevated $\mathrm{O}_{3}(P \leq 0.018$ and $P \leq 0.038$; Figures 1, 3; Appendix Figure 1 in Supplementary material), but there were $\mathrm{CO}_{2} \times$ $\mathrm{O}_{3} \times$ year interactions for each trait $(P \leq 0.061)$. Trees in the $+\mathrm{CO}_{2}$ treatment initially had greater $L_{\text {mass }}, L_{\text {area }}$, and $N_{\text {mass }}$ than trees in both the ambient and $+\mathrm{CO}_{2}+\mathrm{O}_{3}$ treatments, but these differences gradually declined $\left(r^{2} \geq 0.599, P \leq 0.041\right)$. Conversely, trees in the $+\mathrm{O}_{3}$ treatment initially had somewhat lower $L_{\text {mass }}$ and $N_{\text {mass }}$ than trees in the ambient and $+\mathrm{CO}_{2}+\mathrm{O}_{3}$ treatments and these differences gradually increased $\left(r^{2} \geq 0.485, P \leq 0.082\right)$.

For both birch and aspen, $L_{\text {mass }}, L_{\text {areaa }}$ and $N_{\text {mass }}$ were higher under elevated $\mathrm{CO}_{2}$ and lower under elevated $\mathrm{O}_{3}$. However, only the $\mathrm{CO}_{2}$ effect on $L_{\text {area }}$ in birch $(+37 \%, P=0.064)$ and the $\mathrm{CO}_{2}$ effect on $L_{\text {mass }}$ in aspen approached significance $(+47 \%$, $P=0.090)$. Aspen had significant increases through time in $L_{\text {mass }}, L_{\text {arear }}$ and $N_{\text {mass }}$ (Figure 4; Appendix Table 3 in Supplementary material), whereas changes in birch $L_{\text {mass }} L_{\text {arear }}$ and $N_{\text {mass }}$ through time varied by treatment $\left(\mathrm{CO}_{2} \times \mathrm{O}_{3} \times\right.$ year: $P \leq 0.02$, Appendix Table 3 in Supplementary material). Over time, birch $L_{\text {mass }}$ and $N_{\text {mass }}$ decreased in the $+\mathrm{CO}_{2}$ treatment and birch $L_{\text {mass }}$ decreased in the $+\mathrm{O}_{3}$ treatment $(P \leq 0.051$, 
Table 2. Change in Treatment Effects on Overall Leaf Mass Through Time

\begin{tabular}{|c|c|c|c|c|c|}
\hline Contrast & 2002 Effect & 2008 Effect & Annual change & $r^{2}$ & $P$ \\
\hline$+\mathrm{CO}_{2} /$ Ambient & $+52.4 \pm 9.5 \%$ ** & $+24.9 \pm 1.7 \%$ ** & $-4.0 \pm 1.3 \%$ & 0.654 & 0.028 \\
\hline$+\mathrm{O}_{3} /$ Ambient & $-5.5 \pm 4.0 \%$ & $-18.5 \pm 3.6 \% *$ & $-1.8 \pm 0.8 \%$ & 0.481 & 0.084 \\
\hline$+\mathrm{CO}_{2}+\mathrm{O}_{3} /$ Ambient & $+23.0 \pm 11.6 \%$ & $+15.4 \pm 9.9 \%$ & $-0.1 \pm 1.5 \%$ & 0.001 & 0.956 \\
\hline$+\mathrm{CO}_{2}+\mathrm{O}_{3} /+\mathrm{CO}_{2}$ & $-19.3 \pm 4.1 \%$ * & $-7.6 \pm 9.0 \%$ & $2.5 \pm 0.7 \%$ & 0.834 & 0.004 \\
\hline$+\mathrm{CO}_{2}+\mathrm{O}_{3} /+\mathrm{O}_{3}$ & $+30.2 \pm 10.3 \%$ * & $+41.6 \pm 5.9 \% * *$ & $2.8 \pm 0.5 \%$ & 0.649 & 0.029 \\
\hline $\mathrm{CO}_{2}$ Main Effect & $+41.6 \pm 15.2 \%$ ** & $+32.4 \pm 8.3 \% * *$ & $-0.9 \pm 0.9 \%$ & 0.149 & 0.392 \\
\hline $\mathrm{O}_{3}$ Main Effect & $-13.8 \pm 7.7 \%$ & $-12.5 \pm 5.1 \% * *$ & $0.7 \pm 0.5 \%$ & 0.268 & 0.234 \\
\hline
\end{tabular}

Main $\mathrm{CO}_{2}$ and $\mathrm{O}_{3}$ effects defined from factorial treatments, for example $\left(+\mathrm{CO}_{2}\right.$ and $\left.+\mathrm{CO}_{2}+\mathrm{O}_{3}\right) /\left(\right.$ Ambient and $\left.+\mathrm{O}_{3}\right)$. Effects (mean $\left.\pm \mathrm{SE}\right)$ with $\mathrm{P}<0.05$ are in bold. Significant pair-wise comparisons noted by ** for $P<0.05$ and * for $P<0.10 . r^{2}$ and $P$ values derived from linear regressions of annual effect size data pooled across communities.

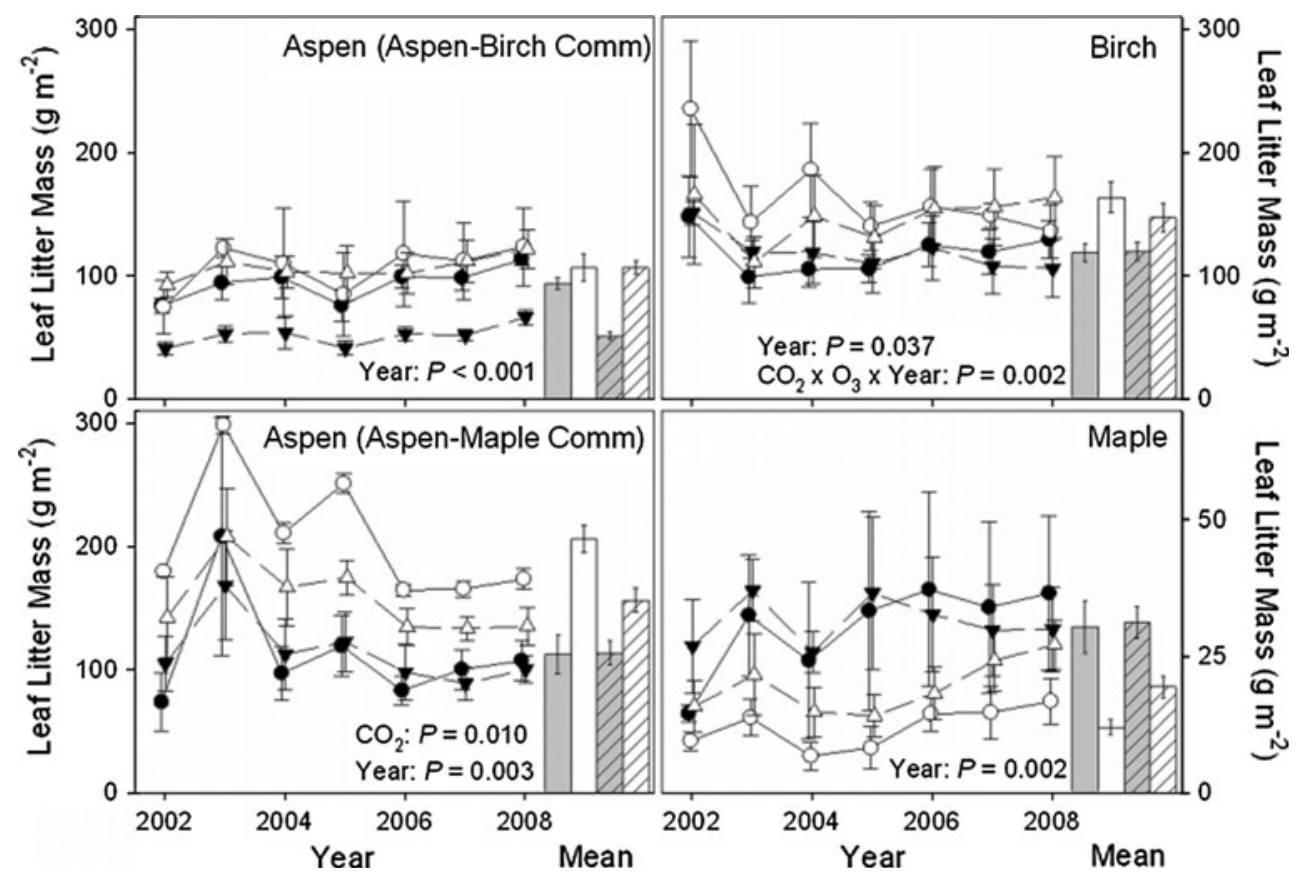

Figure 4. Annual leaf mass $\left(\mathrm{g} \mathrm{m}^{-2}\right)$ of the individual components (species) in the mixedspecies communities (aspen-birch and aspenmaple) for each fumigation treatment. Bars as in Figure 1. All results where $P \leq 0.05$ in the repeated measures ANOVA conducted for each species are reported. Note the difference in scale for maple. Full statistical results for each community component are in Appendix Table 3 (Supplementary material).
Figure 4$)$. Birch $L_{\text {mass }}$ and $N_{\text {mass }}$ increased with time in the $+\mathrm{CO}_{2}+\mathrm{O}_{3}$ treatment $(P \leq 0.097)$. The $L_{\text {mass, }} L_{\text {area, }}$ and $N_{\text {mass }}$ of birch were larger for trees in the $+\mathrm{CO}_{2}$ treatment than in trees growing in the ambient and $+\mathrm{CO}_{2}+\mathrm{O}_{3}$ treatments, but these differences declined with time $\left(r^{2} \geq 0.472\right.$, $P \leq 0.088)$. The same three properties declined with time for trees in the $+\mathrm{O}_{3}$ treatment relative to trees in both the ambient and $+\mathrm{CO}_{2}+\mathrm{O}_{3}$ treatments $\left(r^{2} \geq 0.645, P \leq 0.030\right.$, except $+\mathrm{O}_{3} /$ ambient for $N_{\text {mass }}$ where $r^{2}=0.290, P=0.212$ ).

At the community level, $N_{\text {conc }}$ was $1.4 \mathrm{mg} \mathrm{g}^{-1}$ lower for leaves in the $+\mathrm{CO}_{2}$ treatment than for leaves in the ambient treatment $(P=0.074$, $\mathrm{CO}_{2} \times \mathrm{O}_{3}: P=0.052$, Figure 2). In aspen, leaves in the ambient treatment had $1.9 \mathrm{mg} \mathrm{g}^{-1}$ more $\mathrm{N}$ than leaves in the $+\mathrm{CO}_{2} \quad(P=0.025)$ and $+\mathrm{CO}_{2}+\mathrm{O}_{3}$ $(P=0.027)$ treatments and $1.4 \mathrm{mg} \mathrm{g}^{-1}$ more $\mathrm{N}$ than leaves in the $+\mathrm{O}_{3}$ treatment $\left(P=0.086, \mathrm{CO}_{2} \times \mathrm{O}_{3}\right.$ :
$P=0.074)$. There were no significant effects on $N_{\text {conc }}$ in birch $(P>0.15)$.

Within the aspen-birch community, there was a $\mathrm{CO}_{2} \times \mathrm{O}_{3} \times$ year interaction for the proportional contribution of aspen to community $L_{\text {mass }}(P=0.013$, Figure 4). Here, early increases in the proportional contribution of aspen in the $+\mathrm{CO}_{2}$ and $+\mathrm{O}_{3}$ treatments relative to both the ambient and $+\mathrm{CO}_{2}+\mathrm{O}_{3}$ treatments declined over time $\left(r^{2} \geq 0.544, P \leq 0.04\right)$.

\section{Aspen-Maple Community}

For the aspen-maple community, there were no significant trends with time overall or interactions between year and the fumigation treatments for $L_{\text {mass, }} L_{\text {area, }}$ and $N_{\text {mass }}(P \geq 0.249$, Appendix Table 3 in Supplementary material). Community $L_{\text {mass }}$ $L_{\text {arear }}$ and $N_{\text {mass }}$ were significantly increased by elevated $\mathrm{CO}_{2}(P \leq 0.047)$ and decreased by 
elevated $\mathrm{O}_{3}$, but only the difference in $L_{\text {area }}$ approached significance for $\mathrm{O}_{3}(P=0.097$; Figures 1 , 3; Appendix Figure 1 in Supplementary material).

At the species level, there were significant decreases over time in aspen $L_{\text {mass }}$ and $N_{\text {mass }}$ (Appendix Table 3 in Supplementary material). Maple $L_{\text {mass }}$ and $L_{\text {area }}$ significantly increased over time, whereas maple $N_{\text {conc }}$ decreased over time (Appendix Table 3 in Supplementary material).

The effects of $\mathrm{CO}_{2}$ and of $\mathrm{O}_{3}$ were unique in maple: elevated $\mathrm{CO}_{2}$ decreased $L_{\text {area }}(-46 \%$, $P=0.066)$ and $N_{\text {mass }}(-47 \%, P=0.079)$, whereas elevated $\mathrm{O}_{3}$ slightly (but not significantly) increased $L_{\text {mass }}, L_{\text {area }}$, and $N_{\text {mass }}(+15 \%$, Figure 4$)$. For aspen, $L_{\text {mass }}, L_{\text {area }}$ and $N_{\text {mass }}$ were increased by elevated $\mathrm{CO}_{2}$ (all $P \leq 0.012$ ) and decreased under elevated $\mathrm{O}_{3}$, but the $\mathrm{O}_{3}$ effects were not significant $(P \geq 0.102)$. There were $\mathrm{CO}_{2} \times \mathrm{O}_{3} \times$ year interactions for maple $L_{\text {mass }}(P=0.069$, Figure 4$)$ and $N_{\text {mass }}(P=0.068)$. These interactions stem from a steady change from a positive effect of the $+\mathrm{O}_{3}$ treatment relative to the ambient treatment in $L_{\text {mass }}$ and $N_{\text {mass }}$ to a negative effect $\left(r^{2} \geq 0.491\right.$, $P \leq 0.079$ ) and a decreasing difference between trees in the $+\mathrm{O}_{3}$ treatment and trees in the $+\mathrm{CO}_{2}+\mathrm{O}_{3}$ treatment for $L_{\text {mass }}\left(r^{2}=0.459\right.$, $P=0.094)$ and $N_{\text {mass }}\left(r^{2}=0.666, P=0.025\right)$.

The only significant treatment effect on $N_{\text {conc }}$ was a $0.9 \mathrm{mg} \mathrm{g}^{-1}$ decrease in aspen caused by elevated $\mathrm{CO}_{2}(P=0.012)$.

\section{Discussion}

\section{Changes in $\mathrm{CO}_{2}$ and $\mathrm{O}_{3}$ Effects Through Time}

Over the 7 years of this study (years five through eleven of the experiment), there were clear changes in the effects of the individual fumigation treatments (Table 2). Most dramatically, the average stimulation of $L_{\text {mass }}$ by the elevated $\mathrm{CO}_{2}$ treatment $\left(+\mathrm{CO}_{2}\right)$ compared to current ambient conditions $\left(+\mathrm{CO}_{2} /\right.$ ambient) dropped by more than half (Figure 1; Table 2). This transient response to $+\mathrm{CO}_{2}$ has been observed in several experiments (Norby and others 1999; Körner 2006). It appears that the initial stimulation of growth by elevated $\mathrm{CO}_{2}$ allows forests to more quickly reach the point in stand development where environmental factors (light, water, nutrients, and so on) limit canopy production, but eventually, trees growing under ambient conditions reach a similar set of limitations to growth (Körner 2006). For example, in coppiced Populus forests (Gielen and others 2003), a stimulatory effect of elevated $\mathrm{CO}_{2}$ on leaf area was observed only until canopy closure, after which responses declined markedly. A similar pattern appears in our study, where the declining $+\mathrm{CO}_{2}$ effect was most apparent in the aspen-birch community. In 2002, trees in the $+\mathrm{CO}_{2}$ treatment for this community had a $L_{\text {area }}$ of $4.1 \pm 0.2 \mathrm{~m}^{2} \mathrm{~m}^{-2}$, whereas trees in the ambient treatment had a $L_{\text {area }}$ of $2.9 \pm 0.2 \mathrm{~m}^{2} \mathrm{~m}^{-2}$. By 2008, trees in both treatments had similar $L_{\text {area }}$ values $\left(4.3 \pm 0.5\right.$ for $+\mathrm{CO}_{2}, \quad 4.1 \pm 0.2$ for ambient; Appendix Figure 1 in Supplementary material). This response is less apparent in the aspen-only and aspen-maple communities, but the aspen-only community continued to add both $L_{\text {area }}$ and $L_{\text {mass }}$ throughout this study and in the aspen-maple community, $L_{\text {area }}$ and $L_{\text {mass }}$ were considerably lower than in the aspen-birch community and displayed high inter-annual variability (Figure 1). Our overall results are evidence that, relative to ambient conditions, the $+\mathrm{CO}_{2}$ stimulation of leaf production has declined. Although this decline in the $+\mathrm{CO}_{2}$ stimulation has also been observed in annual measures of stem growth (1997-2004; Kubiske and others 2006), some continued stimulation of net primary productivity by the $+\mathrm{CO}_{2}$ treatment relative to ambient is likely because of increases in leaf longevity and leaflevel photosynthesis in the $+\mathrm{CO}_{2}$ treatment (Riikonen and others 2008).

Although the declining $\mathrm{CO}_{2}$ stimulation of leaf production observed here is supported by theory (Körner 2006) and observations from similar experiments (for example, Gielen and others 2003), less is known about the long-term response of forests to elevated $\mathrm{O}_{3}$. In earlier work (19972004) at Rhinelander FACE, Kubiske and others (2006) found that the negative effect of the $+\mathrm{O}_{3}$ treatment on the relative rate of tree growth was dissipating. However, we observed an increasingly negative effect of the $+\mathrm{O}_{3}$ treatment relative to the ambient treatment on $L_{\text {mass }}$ in the aspen-birch community and to a lesser extent in the overall experiment (Figure 1; Table 2). In terms of its consequences for net primary production, the increasingly negative effect of the $+\mathrm{O}_{3}$ treatment on $L_{\text {mass }}$ is magnified by the reductions in leaf-level $\mathrm{C}$ uptake caused by the lower rates of leaf-level photosynthesis and shorter leaf longevity also observed at Rhinelander FACE (Riikonen and others 2008). Increasing $\mathrm{O}_{3}$ effects on plant growth have also been found in several other experiments and are likely related to these changes in leaf $\mathrm{C}$ uptake (Oksanen 2003; Ottosson and others 2003; Volk and others 2006). In these cases, current year $\mathrm{O}_{3}$ effects may be compounded due to reduction in the pool of plant resources available to initiate shoot growth due to $\mathrm{O}_{3}$ effects that accumulated in 
the previous growing season (for example, C reserves, bud size; Oksanen and Saleem 1999; Oksanen 2003). At Rhinelander FACE in 2005, Riikonen and others (2008) found that the size of aspen buds and the starch content of birch buds were lower in the $+\mathrm{O}_{3}$ treatment. However, this mechanism does not seem to be affecting leaf mass in the aspen-only and aspen-maple communities, where there is no evidence that trees in the $+\mathrm{O}_{3}$ treatment added or lost leaf mass at a different rate than those in the ambient treatment (as evident from the lack of significant $\mathrm{O}_{3} \times$ year or $\mathrm{CO}_{2} \times \mathrm{O}_{3} \times$ year effects). In fact, the $+\mathrm{O}_{3}$ treatment has had little effect relative to ambient on the $L_{\text {mass }}$ of either species in the aspen-maple community (Figure 4). Although maple (Acer saccharum) is relatively insensitive to elevated $\mathrm{O}_{3}$ (Noble and others 1992; Rebbeck and Loats 1997), we are not able to explain why there has been no reduction in aspen leaf mass in this community. For the aspen-only community, Kubiske and others (2007) found using measurements of tree survival and stem volume during the first 8 years of the experiment that the $+\mathrm{O}_{3}$ treatment had diminished the relative importance of $\mathrm{O}_{3}$-sensitive clones and increased the importance of $\mathrm{O}_{3}$-tolerant clones.

There were also transient effects when $L_{\text {mass }}$ in the $+\mathrm{CO}_{2}$ and $+\mathrm{O}_{3}$ treatments were compared to $L_{\text {mass }}$ in the interaction $\left(+\mathrm{CO}_{2}+\mathrm{O}_{3}\right)$ treatment: the $\mathrm{O}_{3}$ effect gradually decreased under elevated $\mathrm{CO}_{2}$ $\left(+\mathrm{CO}_{2}+\mathrm{O}_{3} /+\mathrm{CO}_{2}\right)$ and the $\mathrm{CO}_{2}$ effect under elevated $\mathrm{O}_{3}$ gradually increased $\left(+\mathrm{CO}_{2}+\mathrm{O}_{3} /+\mathrm{O}_{3}\right.$, Table 2). There are few other multi-year experiments that have exposed trees to $+\mathrm{CO}_{2}+\mathrm{O}_{3}$, but a chamber experiment exposing Liriodendron tulipifera (L.) seedlings to 5 years of $+\mathrm{O}_{3}$ and $+\mathrm{CO}_{2}+\mathrm{O}_{3}$ also found increasingly greater plant growth over time under $+\mathrm{CO}_{2}+\mathrm{O}_{3}$ compared to $+\mathrm{O}_{3}$ (Rebbeck and Scherzer 2002). In our experiment, community $L_{\text {mass }}$ and $L_{\text {area }}$ in the $+\mathrm{CO}_{2}+\mathrm{O}_{3}$ treatment were similar (often slightly greater) to community $L_{\text {mass }}$ and $L_{\text {area }}$ in the ambient treatment (Figures 1, 4; Appendix Figure 1 in Supplementary material). This is unsurprising because $\mathrm{CO}_{2}$ and $\mathrm{O}_{3}$ often have counteracting effects on plant growth (Mulchi and others 1992; Volin and others 1998; Gaucher and others 2003). It is clear from the Rhinelander FACE experiment that this counter-action can be longlasting.

\section{Effects of $\mathrm{CO}_{2}$ and $\mathrm{O}_{3}$ on Species Dominance}

Kubiske and others (2007) analyzed tree growth at Rhinelander FACE from 1997 to 2004 and found that elevated $\mathrm{CO}_{2}$ and elevated $\mathrm{O}_{3}$ had each shifted the relative dominance of species or genotypes within the three forest community types. Such shifts are important because changes in species abundance can have large effects on communitylevel properties such as litter chemistry or productivity (Bradley and Pregitzer 2007). Both in our study and in the analysis of tree growth (Kubiske and others 2007), the greatest effect of elevated $\mathrm{CO}_{2}$ was an increase in the relative dominance of aspen in the aspen-maple community. In general, species with greater relative growth rates are more sensitive to elevated $\mathrm{CO}_{2}$ and show stronger responses (Poorter and Navas 2003). Our results are consistent with this finding because of the three species included in the experiment, aspen and birch exhibit high relative growth rates, whereas maple is slower growing (Kubiske and others 2007).

Earlier in the development of the forests at Rhinelander FACE (through 2004), it was noted that the $+\mathrm{CO}_{2}$ treatment affected birch more favorably than aspen in both growth and mortality (Kubiske and others 2007). Birch also appeared competitively favored by $+\mathrm{O}_{3}$ in this earlier analysis (Kubiske and others 2007). However, these effects disappeared during the 2002-2008 leaf collections. Here, the proportional contribution of aspen to community $L_{\text {mass }}$ increased in all treatments (Figure 4 ), but the declines in birch $L_{\text {mass }}$ in the $+\mathrm{CO}_{2}$ and $+\mathrm{O}_{3}$ treatments meant that increases in the contribution of aspen were stronger in these treatments. Although the contrasting trends between the earlier analysis and this study possibly reflect differences in the way dominance was measured ( $L_{\text {mass }}$ versus stem volume), it is more likely that the current trends reflect changes over time in how competition between these species is altered by $\mathrm{CO}_{2}$ and $\mathrm{O}_{3}$.

\section{Canopy Nitrogen Cycling}

As predicted, there was not a significant overall $\mathrm{CO}_{2}$ effect on $N_{\text {conc }}$. However, there was a modest overall $\mathrm{O}_{3}$ effect and elevated $\mathrm{CO}_{2}$ did significantly reduce $N_{\text {conc }}$ for aspen in the mixed-species communities. These results are not surprising given similarly mixed findings in previous $N_{\text {conc }}$ measurements at Rhinelander FACE for $\mathrm{CO}_{2}$ and $\mathrm{O}_{3}$ effects in green foliage (Kopper and others 2001; Takeuchi and others 2001; Zak and others 2007) and leaf litter (Liu and others 2007, Parsons and others 2008). More consistent at Rhinelander FACE is the finding that $N_{\text {mass }}$ has been increased by elevated $\mathrm{CO}_{2}$ and decreased by elevated $\mathrm{O}_{3}$ (this study, Liu and others 2007; Zak and others 2007). 
A similar increase in $N_{\text {mass }}$ under elevated $\mathrm{CO}_{2}$ was observed at Duke Forest FACE (Finzi and others 2001; Drake and others 2011). In contrast, in other forest FACE experiments, $N_{\text {mass }}$ has decreased (Cotrufo and others 2005) or there has been no evidence of change in $N_{\text {mass }}$ or the pool of green leaf $\mathrm{N}$ (Körner and others 2005; Norby and Iversen 2006).

A stimulation of $\mathrm{N}$ uptake by elevated $\mathrm{CO}_{2}$ at Rhinelander FACE has also been observed for roots, stems, and branches (Zak and others 2007). This increase in $\mathrm{N}$ uptake rather than an increase in $\mathrm{N}$-use efficiency appears to be supporting higher productivity under elevated $\mathrm{CO}_{2}$ at Rhinelander FACE (Finzi and others 2007). In addition to the increases in $\mathrm{N}$ uptake, the increase in $\mathrm{N}$ mineralization (Holmes and others 2006), the greater activity of cellulose-degrading extracellular enzymes (Larson and others 2002), and the lack of soil C accumulation (Talhelm and others 2009) are strong evidence that the additional leaf litter (Figure 1), root litter (Pregitzer and others 2008), and total belowground carbon flux (Giardina and others 2005) under elevated $\mathrm{CO}_{2}$ is quickly processed by the microbial community. Thus, rather than creating the negative feedbacks on plant $\mathrm{N}$ supply that would be consistent with an ecosystem experiencing progressive $\mathrm{N}$ limitation (Luo and others 2004), the rate of $\mathrm{N}$ cycling has increased under elevated $\mathrm{CO}_{2}$ (Zak and others 2007). In comparison, elevated $\mathrm{O}_{3}$ has had effects that suggest a slowed $\mathrm{N}$ cycle: decreased $L_{\text {mass }}$ (Figure 1) with no corresponding reduction in soil C (Talhelm and others 2009), lower plant $\mathrm{N}$ uptake (Zak and others 2007), and reduced $\mathrm{N}$ mineralization (Holmes and others 2006).

\section{Summary and Implications}

This study was unique in that we were able to examine how leaf production and litter nitrogen in developing northern temperate forest communities of varying composition responded to relatively longterm fumigation (11 years) with elevated atmospheric $\mathrm{CO}_{2}$ and/or tropospheric $\mathrm{O}_{3}$. This allowed us insight into how these important gases, which will become more abundant in the atmosphere over the next century, interacted with each other and with ecological factors such as species identity, stand development, and nitrogen availability. Although we observed consistent main effects of $\mathrm{CO}_{2}$ (positive) and $\mathrm{O}_{3}$ (negative) on community $L_{\text {mass, }} L_{\text {arear }}$ and $N_{\text {mass }}$, there were significant $\mathrm{CO}_{2} \times \mathrm{O}_{3} \times$ year and $\mathrm{CO}_{2} \times \mathrm{O}_{3} \times$ community interactions (Table 1), wherein the differences between individual fumigation treatments changed through time (Table 2) and varied by community (Figure 1). For instance, we observed a declining stimulation of leaf production by elevated $\mathrm{CO}_{2}$ under ambient $\mathrm{O}_{3}$, but an increasing stimulation leaf production by elevated $\mathrm{CO}_{2}$ under elevated $\mathrm{O}_{3}$ (Table 2). There is little evidence these changes resulted from reduced $\mathrm{N}$ availability (Figure 2). As has been observed elsewhere (Gielen and others 2003), it instead appears that the $+\mathrm{CO}_{2}$ treatment affected leaf production largely by advancing the rate of stand development rather than by increasing the long-term community capacity to produce leaves. When comparing trees in the $+\mathrm{O}_{3}$ treatment to those growing under ambient conditions, we found evidence supporting the idea that the negative effects of this gas on leaf production can be cumulative, compounding leaf-level effects to reduce plant $\mathrm{C}$ uptake. Perhaps most importantly, when trees were exposed to the treatment most likely to represent the future composition of the atmosphere $\left(+\mathrm{CO}_{2}+\mathrm{O}_{3}\right)$, community $L_{\text {mass, }} L_{\text {area }}$ and $N_{\text {mass }}$ were not significantly different than under ambient conditions (Figures 1, 2, 4; Appendix Figure 1 in Supplementary material). However, although these results could be construed to imply that future forests will be functionally similar to current forests, there is considerable evidence that communities exposed to $+\mathrm{CO}_{2}+\mathrm{O}_{3}$ and ambient conditions differ strongly in important functional attributes such as community composition (Kubiske and others 2007) and belowground C cycling (Pregitzer and others 2008; Talhelm and others 2009). Predictions regarding the future function of northern temperate forests are further complicated by the fact that species and communities showed a range of responses to the treatment gases (for example, Figures 3,4).

\section{ACKNOWLEDGMENTS}

We would like to thank Angela Piket and Jennifer Eikenberry for help in the field and lab. Peter Weisberg, Dale Johnson, and two anonymous reviewers provided helpful comments on earlier drafts. Rhinelander FACE is supported by the U.S. Department of Energy's Office of Biological and Environmental Research and the U.S. Forest Service.

\section{REFERENCES}

Ainsworth EA, Long SP. 2005. What have we learned from 15 years of free-air $\mathrm{CO}_{2}$ enrichment (FACE)? A meta-analytic review of the responses of photosynthesis, canopy properties and plant production to rising $\mathrm{CO}_{2}$. New Phytol 165:351-72.

Bradley KL, Pregitzer KS. 2007. Ecosystem assembly and terrestrial carbon balance under elevated $\mathrm{CO}_{2}$. Trends Ecol Evol 22:538-47. 
Chappelka AH, Samuelson LJ. 1998. Ambient ozone effects on forest trees of the eastern United States: a review. New Phytol 139:91-108.

Cotrufo MF, De Angelis P, Polle A. 2005. Leaf litter production and decomposition in a poplar short-rotation coppice exposed to free air $\mathrm{CO}_{2}$ enrichment (POPFACE). Glob Change Biol 11:971-82.

Dentener F, Stevenson D, Ellingsen K, van Noije T, Schultz M, Amann M, Atherton C, Bell N, Bergmann D, Bey I et al. 2006. The global atmospheric environment for the next generation. Environ Sci Technol 40:3586-94.

Dickson RE, Lewin KF, Isebrands JG, Coleman MD, Heilman WE, Riemenschneider DE, Sober J, Host GE, Zak DR, Hendrey GR, et al. 2000. Forest atmosphere carbon transfer storage-II (FACTS II) - The aspen free-air $\mathrm{CO}_{2}$ and $\mathrm{O}_{3}$ enrichment (FACE) project in an overview. USDA Forest Service North Central Research Station. General Technical Report NC-214. $68 \mathrm{pp}$.

Drake JE, Gallet-Budynek A, Hofmockel KS, Bernhardt ES, Billings SA, Jackson RB, Johnsen KS, Lichter J, McCarthy HR, McCormack ML et al. 2011. Increases in the flux of carbon belowground stimulate nitrogen uptake and sustain the longterm enhancement of forest productivity under elevated $\mathrm{CO}_{2}$. Ecol Lett 14:349-57.

Finzi AC, Allen AS, DeLucia EH, Ellsworth DS, Schlesinger WH. 2001. Forest litter production, chemistry, and decomposition following two years of free-air $\mathrm{CO}_{2}$ enrichment. Ecology 82:470-84.

Finzi AC, Norby RJ, Calfapietra C, Gallet-Budynek A, Gielen B, Holmes WE, Hoosbeek MR, Iversen CM, Jackson RB, Kubiske $M E$ et al. 2007. Increases in nitrogen uptake rather than nitrogen-use efficiency support higher rates of temperate forest productivity under elevated $\mathrm{CO}_{2}$. Proc Natl Acad Sci 104:14014-19.

Gaucher C, Costanzo N, Afif D, Maufette Y, Chevrier N, Dizengremel P. 2003. The impact of elevated ozone and carbon dioxide on young Acer saccharum seedlings. Physiol Plant 117:392-402.

Giardina CP, Coleman MD, Binkley D, Hancock JE, King JS, Lilleskov EA, Loya WM, Pregitzer KS, Ryan MG, Trettin CC. 2005. The response of belowground carbon allocation in forests to global change. In: Binkley D, Menyailo O, Eds. Tree species effects on soils: implications for global change. NATO Science Series. Dordrecht: Kluwer Academic Publishers. p $119-54$.

Gielen B, Liberloo M, Bogaert J, Calfapietra C, DeAngelis P, Miglietta F, Scarascia-Mugnozza G, Ceulemans R. 2003. Three years of free-air $\mathrm{CO}_{2}$ enrichment (POPFACE) only slight affect profiles of light and leaf characteristics in closed canopies of Populus. Glob Change Biol 9:1022-37.

Hendrey GR, Ellsworth DS, Lewin KF, Nagy J. 1999. A free-air enrichment system for exposing tall forest vegetation to elevated atmospheric $\mathrm{CO}_{2}$. Glob Change Biol 5:293-300.

Holmes WE, Zak DR, Pregitzer KS, King JS. 2006. Elevated $\mathrm{CO}_{2}$ and $\mathrm{O}_{3}$ alter soil nitrogen transformations beneath trembling aspen, paper birch, and sugar maple. Ecosystems 9:1354-63.

IPCC. 2007. Summary for policymakers. In: Solomon S, Qin D, Manning M, Chen Z, Marquis M, Averyt KB, Tignor M, Miller HL, Eds. Climate Change 2007: The Physical Science Basis. Contribution of Working Group I to the Fourth Assessment Report of the Intergovernmental Panel on Climate Change. Cambridge, UK and New York, NY, USA: Cambridge University Press. 996 pp.
Johnson DW, Cheng W, Joslin JD, Norby RJ, Edwards NT, Todd DE Jr. 2004. Effects of elevated $\mathrm{CO}_{2}$ on nutrient cycling in a sweetgum plantation. Biogeochemistry 69:379-403.

King JS, Kubiske ME, Pregitzer KS, Hendrey GR, McDonald EP, Giardina CP, Quinn VS, Karnosky DF. 2005. Tropospheric $\mathrm{O}_{3}$ compromises net primary production in young stands of trembling aspen, paper birch and sugar maple in response to elevated atmospheric $\mathrm{CO}_{2}$. New Phytol 168: 623-36.

Kopper BJ, Lindroth RL, Nordheim EV. 2001. $\mathrm{CO}_{2}$ and $\mathrm{O}_{3}$ effects on paper birch (Betulaceae: Betula papyrifera Marsh.) phytochemistry and white-marked tussock moth (Lymantriidae: Orgyia leucostigma J.E. Sm.) performance. Environ Entomol 30:1119-26.

Körner C, Asshoff R, Bignucolo O, Hättenschwiler S, Keel SG, Peláez-Riedl S, Pepin S, Siegwolf RTW, Zotz G. 2005. Carbon flux and growth in mature deciduous forest trees exposed to elevated $\mathrm{CO}_{2}$. Science 309:1360-2.

Körner C. 2006. Plant $\mathrm{CO}_{2}$ responses: an issue of definition, time and resource supply. New Phytol 172:393-411.

Kubiske ME, Quinn VS, Heilman WE, McDonald EP, Marquardt PE, Teclaw RM, Friend AL, Karnosky DF. 2006. Interannual climatic version mediates elevated $\mathrm{CO}_{2}$ and $\mathrm{O}_{3}$ effects on forest growth. Glob Change Biol 12:1054-68.

Kubiske ME, Quinn VS, Marquardt PE, Karnosky DF. 2007. Effects of elevated atmospheric $\mathrm{CO}_{2}$ and/or $\mathrm{O}_{3}$ on intra-and interspecific competitive ability of aspen. Plant Biol 9:34255.

Larson JL, Zak DR, Sinsabaugh RL. 2002. Microbial activity beneath temperate trees growing under elevated $\mathrm{CO}_{2}$ and $\mathrm{O}_{3}$. Soil Sci Soc Am J 66:1848-56.

Littell RC, Milliken GC, Stroup WW, Wolfinger RD. 1996. SAS system for mixed models. Cary, NC: SAS Institute Inc. p 633.

Litton CM, Raich JW, Ryan MG. 2007. Carbon allocation in forest ecosystems. Glob Change Biol 13:2089-109.

Liu L, King JS, Giardina CP. 2007. Effects of elevated atmospheric $\mathrm{CO}_{2}$ and tropospheric $\mathrm{O}_{3}$ on nutrient dynamics: decomposition of leaf litter in trembling aspen and paper birch communities. Plant Soil 299:65-82.

Luo Y, Su B, Currie WS, Dukes JS, Finzi A, Hartwig U, Hungate B, McMurtrie RE, Oren R, Parton WJ. 2004. Progressive nitrogen limitation of ecosystem responses to rising atmospheric carbon dioxide. Bioscience 54:731-40.

McCarthy HR, Oren R, Finzi AC, Johnsen KH. 2006. Canopy leaf area constrains $\left[\mathrm{CO}_{2}\right]$-induced enhancement of productivity and partitioning among aboveground carbon pools. Proc Natl Acad Sci 103:19356-61.

Mulchi CL, Slaughter L, Saleem M, Lee EH, Pausch R, Rowland R. 1992. Growth and physiological characteristics of soybean in open-top chambers in response to ozone and increased atmospheric $\mathrm{CO}_{2}$. Agric Ecosyst Environ 38:107-18.

Nabuurs GJ, Masera O, Andrasko K, Benitez-Ponce P, Boer R, Dutschke M, Elsiddig E, Ford-Robertson J, Frumhoff P, Karjalainen T, et al. 2007. Forestry. In: Metz B, Davidson OR, Bosch PR, Dave R, Meyer LA, Eds. Climate Change 2007: Mitigation. Contribution of Working Group III to the Fourth Assessment Report of the Intergovernmental Panel on Climate Change. Cambridge, UK and New York, NY, USA: Cambridge University Press, pp 543-584.

Noble R, Jensen KF, Ruff BS, Loats K. 1992. Response of Acer saccharum seedlings to elevated carbon dioxide and ozone. Ohio J. Sci. 92:60-2. 
Norby RJ, Wullschleger SD, Gunderson CA, Johnson DW, Ceulemans R. 1999. Tree responses to rising $\mathrm{CO}_{2}$ in field experiments: implications for the future forest. Plant Cell Environ 22:683-714.

Norby RJ, DeLucia EH, Gielen B, Calfapietra C, Giardina CP, King JS, Ledford J, McCarthy HR, Moore DJP, Ceulemans R et al. 2005. Forest response to elevated $\mathrm{CO}_{2}$ is conserved across a broad range of productivity. Proc Natl Acad Sci 102:18052-6.

Norby RJ, Iversen CM. 2006. Nitrogen uptake, distribution, turnover, and efficiency of use in a $\mathrm{CO}_{2}$-enriched sweetgum forest. Ecology 87:5-14.

Oksanen E, Saleem A. 1999. Ozone exposure results in various carry-over effects and prolonged reduction in biomass in birch (Betula pendula Roth). Plant Cell Environ 22:1401-11.

Oksanen E. 2003. Responses of selected birch (Betula pendula Roth) clones to ozone change over time. Plant Cell Environ 26:875-86.

Ottosson S, Wallin G, Skärby L, Karlsson PE, Medin EL, Räntfors M, Pleijel H, Selldén G. 2003. Four years of ozone exposure at high or low phosphorus reduced biomass in Norway spruce. Trees 17:299-307.

Parsons WFJ, Bockheim JG, Lindroth RL. 2008. Independent, interactive, and species-specific responses of leaf litter decomposition to elevated $\mathrm{CO}_{2}$ and $\mathrm{O}_{3}$ in a northern hardwood forest. Ecosystems 11:505-19.

Poorter H, Navas M-L. 2003. Plant growth and competition at elevated $\mathrm{CO}_{2}$ : on winners, losers and functional groups. New Phytol 157:175-98.

Pregitzer K, Burton A, King J, Zak D. 2008. Soil respiration, root biomass, and root turnover following long-term exposure of northern forests to elevated atmospheric $\mathrm{CO}_{2}$ and tropospheric $\mathrm{O}_{3}$. New Phytol 180:153-61.

Rebbeck J, Loats KV. 1997. Ozone effects on seedling sugar maple (Acer saccharum) and yellow-poplar (Liriodendron tuliperfera): gas exchange. Can J For Res 27:1595-605.
Rebbeck J, Scherzer AJ. 2002. Growth responses of yellowpoplar (Liriodendron tuliperfera L.) exposed to 5 years of $\mathrm{O}_{3}$ alone or combined with elevated $\mathrm{CO}_{2}$. Plant. Cell Environ 25:1527-37.

Riikonen J, Kets K, Darbah J, Oksanen E, Sober A, Vapaavuori E, Kubiske ME, Nelson N, Karnosky DF. 2008. Carbon gain and bud physiology in Populus tremuloides and Betula papyrifera under long-term exposure to elevated concentrations of $\mathrm{CO}_{2}$ and $\mathrm{O}_{3}$. Tree Physiol 28:243-54.

Ryan MG, Binkley D, Fownes JH. 1997. Age-related decline in forest productivity: pattern and process. Adv Ecol Res 27:21362.

Talhelm AF, Pregitzer KS, Zak DR. 2009. Species-specific responses to atmospheric carbon dioxide and tropospheric ozone mediate changes in soil carbon. Ecol Lett 12:1219-28.

Takeuchi Y, Kubiske ME, Isebrands JG, Pregitzer KS, Hendrey G, Karnosky DF. 2001. Photosynthesis, light and nitrogen relationships in a young deciduous forest canopy under open-air $\mathrm{CO}_{2}$ enrichment. Plant Cell Environ 24:1257-68.

Volk M, Bungener P, Contat F, Montani M, Fuhrer J. 2006. Grassland yield declined by a quarter in 5 years of free-air ozone fumigation. Glob Change Biol 12:74-83.

Volin JC, Reich PB, Givnish TJ. 1998. Elevated carbon dioxide ameliorates the effects of ozone on photosynthesis and growth: species respond similarly regardless of photosynthetic pathway or plant functional group. New Phytol 138:315-25.

Wittig VE, Ainsworth EA, Naidu SL, Karnosky DF, Long SP. 2009. Quantifying the impact of current and future tropospheric ozone on tree biomass, growth, physiology and biochemistry: a quantitative meta-analysis. Glob Change Biol 15:396-424.

Zak DR, Holmes WE, Pregitzer KS. 2007. Atmospheric $\mathrm{CO}_{2}$ and $\mathrm{O}_{3}$ alter the flow of ${ }^{15} \mathrm{~N}$ in developing forest ecosystems. Ecology 88:2630-9. 